\title{
PROFESSIONAL JUDGEMENT IN ACCOUNTING: CONTENTS AND CONDITIONS OF APPLICATION
}

\author{
Olena FOMINA®, Oleksandr ZADNIPROVSKY ®i, Svitlana KOROL $\mathbb{1}^{*}$, \\ Olha ROMASHKOD
}

\author{
Department of Accounting and Taxation, Kyiv National University of Trade and Economy, Kyiv, Ukraine
}

Received 10 August 2020; accepted 19 October 2021

\begin{abstract}
The article considers the theoretical prerequisites and regulatory requirements that determine the practical approaches to the application of professional judgment in defining the best way to present reporting information. In the course of the research, the authors took as a basis the regulatory documents on the preparation of financial and integrated reporting, which take a principles-based approach and provide for the use of professional judgment. The authors assumed that the objects of a professional accountant are the facts of economic activity in order to identify, evaluate, recognize and reflect in the accounting and reporting of the company objects of accounting that are significant and of interest to users. The author investigated theoretical bases and practical aspects of application of professional judgment with the purpose of recognition of object and definition of its cost in the course of data collection, their analysis, and formation on their basis of professional judgment. The author has proved the need to adhere to the principle of additionality in finding the maximum complete description of the object and formulating a professional judgement about it. The author proposed a matrix model, which established the correspondence of risk levels and principles of application of professional judgment in accounting valuation and conducted an analysis of the conditions for the use of professional judgment in defining the fair value of financial instruments and inventories. The author considered the influence of uncertainties and corresponding risks in the application of professional judgment on the value of financial instruments and its adjustment in the conditions of unstable markets of countries with economies in transition. The author noted peculiarities of implementation of professional judgment in the process of preparation of financial and integrated reporting and the factors that determine them.
\end{abstract}

Keywords: professional judgement, financial reporting, integrated reporting, valuation of objects of accounting, recognition of objects of accounting, financial instruments, inventories, risk of subjectivity, risk of uncertainty.

JEL Classification: M41, M42, D81.

\section{Introduction}

The globalization of economic systems and the rapid development of information technology have led to the transformation of the accounting paradigm in most countries, the exit from the broad regulation system, and the formation of an accounting reporting system based on principles. At the same time, there is a need to apply the professional judgment of the accountant.

Thus, the Conceptual Framework of International Financial Reporting Standards (IFRS) is traditionally based on the parallel application of regulatory and professional regulation tools. This approach provides variability of thinking and therefore involves the use of professional judgment. The implementation of International Integrated Reporting Framework (IIRF), which does not provide specific performance indicators or evaluation methods at all, further highlights the need for the professional judgment of the accountant.

Even though both IFRS and IIRF contain a direct requirement to apply professional judgment in certain cases, these regulations, as well as Ukrainian law do not define this concept. As a result, approaches to its understanding and interpretation should be developed by the professional community. Thus, the Institute of Certified Public Accountants has prepared a Guidance on Professional Judgment for CPAs, where the term "professional judgment" is considered as "the application of relevant training, knowledge, and experience, within the context provided by auditing, accounting, and ethical standards, in making informed decisions" (The Chinese Institute of Certified Public Accountants, 2016).

${ }^{*}$ Corresponding author. E-mail: s.korol@knute.edu.ua

Copyright $\odot 2022$ The Author(s). Published by Vilnius Gediminas Technical University

This is an Open Access article distributed under the terms of the Creative Commons Attribution License (http://creativecommons.org/licenses/by/4.0/), which permits unrestricted use, distribution, and reproduction in any medium, provided the original author and source are credited. 
In the outline of the International Accounting Standards Board [IASB] documents, the concept of professional judgment is used repeatedly. In particular, it is used in Conceptual Framework for Financial Reporting and IAS 1 Presentation of Financial Statements. At the same time, the requirement to apply professional judgment is aimed at determining the best way to present reporting information.

Therefore, the basic principle of the IAS is the application of professional judgment in all cases where regulatory documents do not provide a specific approach to a particular accounting procedure: the recognition, measurement, or accounting of an object. Finally, the very name of normative documents on the conceptual Framework for Financial Reporting and the International Integrated Reporting Framework essentially implies the application of a set of principles for the formation of certain decisions and judgments.

In the Conceptual Framework for Financial Reporting, it is stated that uncertainty is a characteristic feature of the environment in which the entity operates and on the existence of a certain "degree of uncertainty about the receipt of the entity or disposal of future economic benefits" the need for a balanced probability of occurrence of these events requires the application of professional judgment already at the stage of recognition of the relevant objects and financial statement items. However, one of the hardest areas of professional judgment in the preparation of financial statements is to determine the value of these various objects in the presence of alternative valuation options mechanisms for determining appropriate value to obtain its maximum objective value.

The relevance of professional judgment is growing, and judgments themselves are becoming more subjective and complex as the potential for significant adjustments to the carrying amounts of assets and liabilities increases. As stated in $\$ 127$ IAS 1 Presentation of Financial Statements, this applies, for example, to preliminary estimates for which the number of variables and assumptions that affect the possible future resolution of uncertainties increases. In turn, IAS 8 Accounting Policies, Changes in Accounting Estimates and Errors states that management should use its judgment in developing and applying accounting policies to generate information in the absence of a specific IAS to be applied to an operation, event or condition. Directive 2013/34/EU of the European Parliament and the Council of the European Union on annual financial statements, consolidated financial statements, and related reports of certain types of companies supported this thesis. This Directive provides for the application of preliminary estimates, judgments, and models not only in the valuation of individual items of financial statements but also in their recognition.

Therefore, the possible list of areas of application of professional judgment in accounting and reporting needs to be clarified as well as requirements, conditions, and the procedure for forming a professional judgment.
Our study of professional judgment in accounting valuation is carried out both in theoretical and practical terms from the standpoint of its definition in regulations of four levels: national (in particular, the legislation of countries with economies in transition such as Ukraine), regional (e.g. European Union law) and global (for instance, IAS, IFRS and IIRF), and in a company's internal regulations.

The purpose of the study is to clarify the grounds for the use of professional judgment by an accountant in the process of accounting and reporting.

\section{Literature review}

Many domestic and foreign scholars have studied issues of professional judgment in accounting in their works.

Given the more than 50 years of research experience on this topic (Bonner, 1999), we can note the diversity of aspects to which the authors pay attention. First of all, this is due to the fact that decisions made based on the judgments of the accountant and/or auditor relate to different objects and areas of activity.

However, the attention of domestic and foreign researchers to the topic of professional judgment in accounting and financial reporting is largely related to the processes of convergence of national accounting systems and the introduction of IFRS as national standards. In particular, the connection between these topics is pointed out by Madsen (2011). The researcher argues that at the end of the 20th century, the breadth of professional discourse decreased precisely because of the increase in the number of IASB standards issued. Many publications are devoted to the implementation of the latter. If in the database of Google Scholar there were 3160000 search results for the keywords "International Financial Reporting Standard" at the beginning of the 2020s, then for such a concept as "Professional Judgment in Accounting" - 959000.

The outcomes of the analysis (see Figure 1) indicate that the peak of interest in the topic of "International Financial Reporting Standard" falls on the period of their active implementation in national accounting systems, and recent years are gradually returning to the previous level. However, the problems of professional judgment in accounting remain relevant in the future. In general, this can be explained, according to the apt remark of Heidhues and Patel (2019), by the fact that the IAS provides for extremely significant use of professional judgment. Moreover, with the development of globalization and crisis in national economic systems, the emergence of new objects of reporting, and the emergence of new types of risks, the importance of professional judgment for better coverage. It is at this time, as the graph shows, that researchers are paying more attention to integrated reporting.

In countries with economies in transition, this issue began to arouse interest in the early 2000s. An example of the first detailed publications is the article of Sokolov and 
Terentyeva (2001). The development of the application of professional judgment of an accountant in different situations is reflected in the works of domestic and foreign researchers, in particular Len and Nekhay (2016), Gurina and Doyonko (2019), Yukhimenko-Nazaruk (2016), Tarasova (2017), Derun (2017). Negative aspects of the application of professional judgment of an accountant are analyzed by Golov (2011). Heidhues and Patel (2019) explore factors that may influence professional judgment and provide critical appraisals such as national culture and managerial opportunism.

In particular, Len and Nekhai (2016) expand and clarify the taxonomic basis of the category of professional judgment in accounting, sufficiently cover the areas of its application in various accounting subsystems, consider the general outline of the use of judgment in the preparation of financial statements. However, the practical implementation, and especially the formal aspects of its application to applied objects, in our opinion, have escaped the attention of researchers.

A comparative analysis of the international and national practice of using the professional judgment of the accountant was the subject of research Gurina and Doyonko (2019). The authors correctly identified and analyzed some contradictions in the regulatory framework, which became the drivers of the wider application of professional judgment by accountants. However, as in the previous ones, the authors do not provide possible practical algorithms for the application of professional judgment by accountants.

The issue of risks of professional judgment in the practice of accounting and evaluation has become one of the topics of the study Pankova and Satalkina (2011). Having developed a convenient scheme for classifying risks in the application of judgments in accounting, analyzing in detail the impact of uncertainty in its formation, the authors also do not provide cases on the applied solution of situations in the daily practice of specific objects of accounting. The proposed options for formalizing professional judgment in the works of Kulikova and Gubaidulina (2017) relate only to its use in the preparation of financial statements, leaving out other practical aspects.

In Ukraine, the fundamental works of Knight (1921), Mathews and Perera (1996) are well known, which, among other things, consider the application of professional judgment in accounting.

Noteworthy are several foreign studies in recent years, including Brown-Liburd et al. (2015) on the impact of Big Data on audit judgments; Madsen (2011), Gao and Zhang (2019), Baker (2017) on the level of standardization in the areas of financial reporting and its impact on professional judgments, Bikienè (2011) on the impact of the qualitative judgment on tactical issues on the realization of the strategic financial goals of the institution; Yildiz and Yercan (2011) on the prospects of preparing environmental reporting of industrial enterprises using ERP systems. We agree with the importance to determine the effectiveness of decisions made on the basis of certain judgments and external factors, according to Durkin et al. (2020), Kelly et al. (2019).

Summarizing up, we have to admit that thematically analyzed researches do not go beyond the areas identified by Bonner (1999).

At the same time, the priority for the further study remains to address issues related to the implementation of professional judgment in the application of both a number of IAS and IIRF. In particular:

- use of professional judgment as a tool for valuation and recognition of inventories and financial investments in financial accounting and reporting;

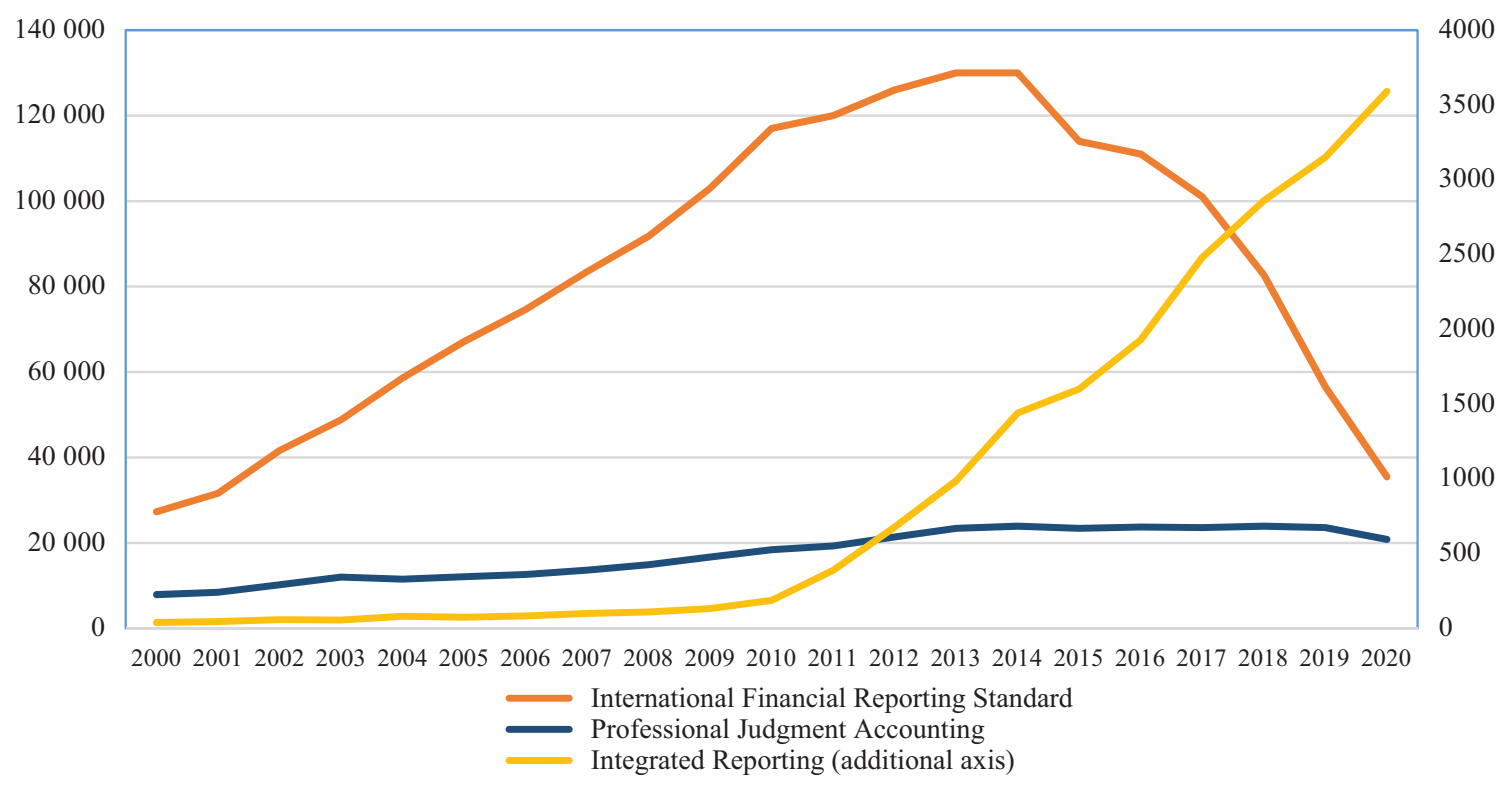

Figure 1. The number of publications in the international scientometric database Google Scholar with keywords "International Financial Reporting Standard", "Professional Judgment in Accounting" and "Integrated Reporting" (source: developed by the authors) 
- identification of the risks associated with the application of professional judgment and issues arising from the implementation of integrated reporting on the measurement of what cannot be measured (Baxter, 2016).

This gives grounds to claim that the topic chosen for research remains relevant due to new objects and aspects of the application of professional judgment in accounting and reporting.

\section{Methods of the study}

Due to the fact that the national standards of accounting and reporting in Ukraine until recently quite fully defined the conditions for valuation, recognition and reflection of most objects, the scope of professional judgment was very limited. Due to the transition to IFRS, the spread of the practice of publishing non-financial and integrated reports, there is a need to apply professional judgment, which is complex and ambiguous in a broad contextual environment. At the same time, as the analysis showed, the use of professional judgments requires consideration of many interrelated factors of influence, which are difficult to quantify. That is why a qualitative approach was chosen to study the conditions of professional judgment in order to help identify the main problems and provide recommendations for their solution (Heidhues \& Patel, 2009).

In particular, the application of a qualitative approach required the solution of the following tasks:

- to clarify the essence of the concept of "professional judgment of an accountant" in the context of institutional economics, i.e. not only its economic but also social, ethical, legal aspects;

- to determine the features and criteria for the use of professional judgment as a practical tool of accounting valuation, on the example of such objects as financial instruments and stocks;

- clarify the requirements, conditions, and principles of formation and application of professional judgment in financial accounting and reporting;

- to analyze the prerequisites of application of professional judgment in the preparation of integrated reporting.

- The applied approach to professional judgment is based on the concepts of accounting and reporting proposed by the IAS and IIRF, as well as scientific publications of Ukrainian and foreign researchers who are interested in solving these problems.

In particular, to illustrate the application of professional judgment in measuring fair value, an analysis of the provisions of IFRS 13 Fair Value Measurement was performed; The concepts in IAS 1 Presentation of Financial Statements are analyzed to determine the extent to which judgments are used in an uncertain setting. The scope and scope of judgment in assessing the most common accounting items, such as inventories, was determined using methods of analysis and comparison with the provisions of the Ukrainian national accounting standard $\mathrm{P}(\mathrm{S}) \mathrm{BO}$ 9 Inventories and IAS 2 Inventories. Innovations of particular importance with the dissemination of integrated reporting, in particular the flexible expansion (with no standardized list) of reporting indicators compared to the traditional approach, were passed through the prism of professional judgment in the application of IIRF and GRI Standards - for which methods were again used analysis, synthesis, and comparison. Finally, the method of statistical analysis of factual data has helped to clarify the breadth and subject profiles of coverage on the subject of professional judgment in professional publications of the last twenty years.

Therefore, the methodological basis of the study is primarily general scientific methods of cognition (analysis and synthesis for processing factual information, induction and deduction, the method of comparison, as well as - the application of the principle of additionality). The application of the principle of additionality to judgment in evaluation is since not all possible applications have a regulated algorithm, and at the same time - the implementation of evaluation judgment in a situation of uncertainty may be inaccurate or even critically incorrect. Therefore, it is possible to apply several simultaneous descriptions to one object of evaluation, each of which will correspond to the objective reality, but at the same time, formally excluding other descriptions, will assume their parallel application.

\section{Results of data analysis}

The need to apply professional judgment in accounting directly depends on the need to choose a situation where there is uncertainty or an alternative. This situation in the system of accounting and reporting is primarily due to the nature of the task or the relevant regulations. For example, valuing or valuing an item has several aspects that require professional judgment.

Assessment is a form of thought that reflects the reflexive attitude of the subject of reasoning to their own and others' statements, as well as to objects (things, objects, processes) of the external and internal world. Estimates concerning the contour of accounting issues belong to the values (axiological) (Vyzhletsov, 2005). Axiological evaluation determines the value of an object, thing, process, idea.

Value (significance of something for someone) is a cultural and philosophical (axiological) category that denotes material or ideal entities (things, processes) that bring good to human life (groups, societies, individuals) when they are applied. Thus, axiological evaluation has expression through value judgment - a concretized statement about values (objects that have any significance, good). Structurally, evaluation is formed by the evaluation attitude, as a subjective experience of the correlation of the objective realities of the world with the material or spiritual needs of the subject performing the evaluation. On the other hand, evaluative judgment is the result of awareness of the evaluative attitude. Evaluation as an axiological 
category is a unity of evaluative attitude (evaluation-process) and evaluative judgment (evaluation-result) (Vyzhletsov, 2005).

A variety of evaluative judgments are professional judgments or evaluative judgments.

The process of implementation and formalization of evaluation is evaluation. The Glossary of Monitoring and Evaluation Terms (Goroshko et al., 2016) provides two approaches to its definition, namely:

- in the general context (assessment) as a process that may be unsystematic, to collect data, analyze them and form judgments based on them;

- in the applied sense (evaluation) as the definition of changes in the implementation of a policy/program/ project, to understand:

- were the planned results achieved?

- how correct were the assumptions about the results of the policy/program/project?

- how effective, efficient, and sustainable are the changes?

For accounting practice, the first approach (preference) should be preferred, as it covers all stages of the cost measurement process and the result obtained (in particular, information on the value of the object). At the same time, an applied understanding of the concept of "evaluation" has application primarily in the field of management accounting, where feedback is essential, the characteristics of the results obtained, and the consequences of its use.

In cognitive psychology, evaluative judgment is a subjective or psychological dimension. Making an evaluative judgment, a person classifies, ranks assigns certain numerical values to objects, events, or other people.

The study of evaluative judgments in the context of decision-making in psychology was initiated in the 50s of the XX century. Simon (1955) formulated the principle of limited rationality. Its essence is that due to the limited cognitive abilities of man, his evaluative judgments and decisions differ significantly from rational ones: they are suboptimal and full of errors.

Simon's views on economic behavior can be explained by the following statements. Individuals are organically limited in their cognitive abilities. Besides, a crucial limitation is related to the structure of the environment where individuals are. Instead of optimizing the choice, they are lead by the principle of sufficiency. Simon called this principle the Scottish dialect word "satisficing" as a result of the merging of two others: sufficing and satisfying. Therefore, as a solution to the problem, the individual chooses the first object that meets his / her level of requirements. It is important to note the double limitation of rational reasoning, on the part of cognitive abilities, and on the part of the environment, which are, in Simon's figurative expression, "behavioral scissors" (Simon, 1955).

Thus, understanding the behavioral motivation of assessment as a psychological process, in a professional application (and in accounting, in particular) it is necessary to have safeguards that will not allow reducing its result to "satisficing".
Uncertainty in accounting mainly arises due to the inability to provide in regulations all possible situations that may emerge in practice. Thus, for many reasons, legislation defines only general principles (or directions) of action. There are also cases where there are no general principles (especially for new objects of accounting), or there may be inconsistencies in the regulatory framework.

The Austro-American researcher of the last century Tintner (1941) expressed the opinion that uncertainty is the result of at least two reasons: "imperfect prediction and inability to solve complex problems with many variables, even when the optimum exists".

As a result, the author faces a vicious circle: there are no regulations for all possible cases, and the implementation of an evaluative judgment in a situation of uncertainty may be inaccurate or even erroneous.

In the author's opinion, such a picture can be explained by applying the principle of additionality, introduced into the methodology of science by Bohr. Its essence is the following: to reproduce the integrity of the phenomenon at a certain stage of its cognition, it is necessary to apply such approaches to the characteristics of the object of evaluation, which are mutually exclusive and mutually limiting. These should be "additional" classes of concepts that can be used separately depending on special (for example, experimental) conditions, but only taken together they exhaustively represent all the information about the object to be described. In this case, the better defined one indicator, the less accurately calculated another related indicator.

Assessing the significance of Bohr's discovery, Born (1963) wrote: the principle of additionality is a completely new way of thinking. Discovered by Bohr, the principle can be applied not only to physics. This method leads to a further liberation from the traditional methodological limitations of thoughts, summarizing important results.

Thus, the principle of additionality is a general scientific methodological statement that allows the need to use different, sometimes opposite, theoretical models to describe one reality. In the author's study, this principle is implied to find the most complete description of the object to form a professional judgment about it. Note also that under the principle of additionality, the professional judgment of the accountant, increases the risk of inaccuracy or even distortion of information and at the same time becomes a tool to reduce overall information risks. The optimality of the decision always implies a risk analysis. Therefore, the task of the accountant is not only to find alternative solutions but primarily to analyze their risks and choose between minimizing risk (costs) and maximizing the possible results (expected income) from the accepted professional judgment. Departing from the rules that do not comply with the principle of reliability, the accountant must explain and justify his professional judgment in the explanations and notes to the financial statements or in the form of a formalized document - in which the formation of the judgment will be given and explained. In this case, the information prepared based on professional judgment must be reliable, the judgment - reasonable and verified. 
Table 1. Matrix model of principles of application of professional judgment in accounting evaluation (source: developed by the authors)

\begin{tabular}{|c|c|c|c|}
\hline \multirow{2}{*}{ Principles } & \multicolumn{3}{|c|}{ Risk levels of professional judgment } \\
\hline & Zero & Middle & High \\
\hline $\begin{array}{l}\text { Condition } \\
\text { for the use of } \\
\text { professional } \\
\text { judgment }\end{array}$ & $\begin{array}{l}\text { Lack of variability of } \\
\text { assessments in regulatory } \\
\text { documents (for example, } \\
\text { assessment of funds in a } \\
\text { bank account) }\end{array}$ & $\begin{array}{l}\text { Availability in regulations of a limited } \\
\text { list of valuation options (e.g. valuation of } \\
\text { inventories at disposal) }\end{array}$ & $\begin{array}{l}\text { Regulatory requirements for the use } \\
\text { of professional judgment (for example, } \\
\text { determining the fair value of financial } \\
\text { instruments) }\end{array}$ \\
\hline $\begin{array}{l}\text { Ability to apply } \\
\text { professional } \\
\text { judgment }\end{array}$ & $\begin{array}{l}\text { The professional judgment is } \\
\text { not provided }\end{array}$ & $\begin{array}{l}\text { Professional judgment is a reasonable } \\
\text { recommendation to choose the best } \\
\text { assessment option from the proposed list } \\
\text { of options }\end{array}$ & $\begin{array}{l}\text { Professional judgment consists both in } \\
\text { the independent development of the } \\
\text { assessment methodology and in the } \\
\text { formulation of its result }\end{array}$ \\
\hline $\begin{array}{l}\text { Risks of } \\
\text { professional } \\
\text { judgment }\end{array}$ & - & $\begin{array}{l}\text { The subjectivity that can lead to } \\
\text { conscious (interest in distorting } \\
\text { information) or unconscious (lack of } \\
\text { competence to make a choice) distortion } \\
\text { of the result }\end{array}$ & $\begin{array}{l}\text { Uncertainty due to lack of sufficient } \\
\text { data on the object of evaluation and } \\
\text { the lack of evaluation methods, the } \\
\text { subjectivity of evaluation (conscious or } \\
\text { unconscious). }\end{array}$ \\
\hline
\end{tabular}

The Institute of Chartered Accountants of Scotland (2016) recommends following the algorithm of actions for the formation of professional judgment, which consists of the following stages:

1. Knowledge gathering and analysis.

2. Assessment of accounting guidance.

3. Process for making a judgement.

4. Documenting the judgment.

This algorithm can be successfully applied in various cases of professional judgment, in particular in accounting valuation. This, in particular, allowed to develop a matrix model of application of professional judgment for accounting evaluation (Table 1).

In this case, it is advisable to include such models in the documents on accounting policies describing the possibilities of using the risks specific to specific businesses and their objects of accounting.

One of the main applications of professional judgment in accounting valuation is the determination of fair value. According to the IAS, accounting items that can be measured at fair value include both financial and some real assets.

Using professional judgment about financial instruments is critical. Their measurement at fair value requires the use of an algorithm for applying a hierarchical structure of data levels for evaluation. This model is based on the provisions of $\$ 38$ and 39 IFRS 13 Fair Value Measurement. It involves the sequential processing of three levels of source data (on the principle of reducing their reliability for evaluation): unadjusted data; data obtained on the market directly or indirectly; indirectly obtained data (see Figure 2). The regression of the reliability of the assessment will increase if the level of initial data on the object of assessment will pass from the 1st to the 2 nd or from the $2 \mathrm{nd}$ to the $3 \mathrm{rd}$. As the range of assessment uncertainty expands, so does the need for professional judgment.

The regression of the reliability of the assessment will increase if the level of the initial data about the object of assessment passes from the 1st to the 2nd or from the 2nd to the 3rd levels. As the range of assessment uncertainty expands, so does the need for professional judgment.

The scope of professional judgment (especially for volatile markets in transition economies) is to adjust the value of facilities to take into account uncertainties and the associated risks in their valuation. The adjustment will allow for some optimization to reflect the uncertainties associated with the risks arising from the pricing or cash flows of the financial instrument. Examples include the following model adjustments:

- adjustment taking into account credit risk. Some models do not take into account credit risk, including the risk of default by the counterparty or its own credit risk;

- adjustment taking into account liquidity risk. In this case, the average market price of the instrument can be calculated, even if the concept of preparation of financial statements provides for the use of the amount adjusted for liquidity (in particular, the difference between the purchase and sale price). Thus, when applying the liquidity adjustment, which is more dependent on professional judgment, it can be found that some financial instruments are illiquid. It will significantly reduce their cost;

- adjustment taking into account other risks. The value determined using a model that does not take into account all other factors that market participants would take into account when setting the price of a financial instrument may not be fair at the valuation date. It is advisable to adjust this assessment separately.

Adjustments will not achieve the objective if the amount of the estimated value of the financial instrument obtained does not meet the fair value of the relevant financial reporting concept. An example is an adjustment using a more conservative (minimalist) approach to valuation.

The most reliable evidence of the fair value of a financial instrument will be the prices of current transactions 


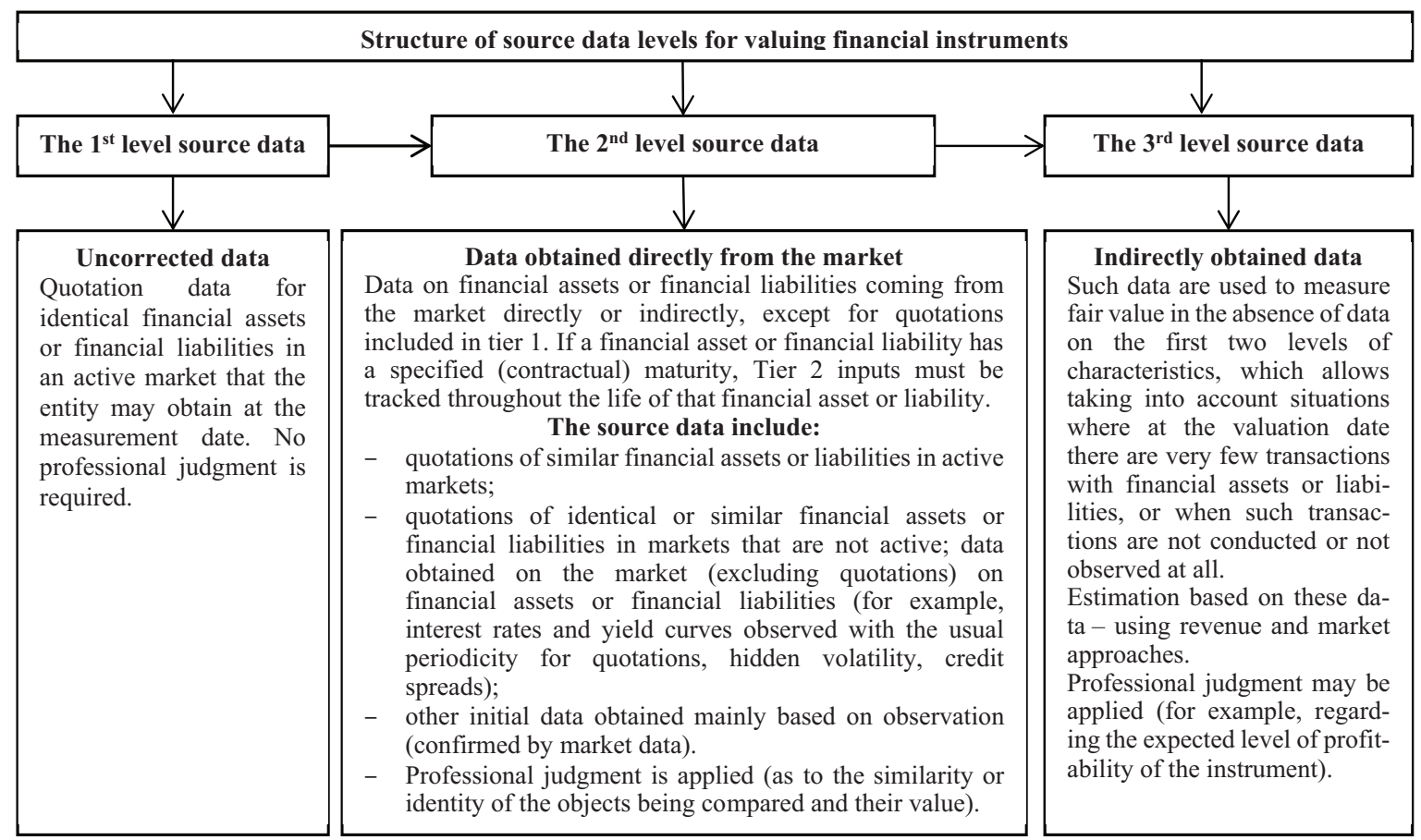

Figure 2. The hierarchical model of data structure for measuring the fair value of financial instruments and applying professional judgment under IFRS 13 Fair Value Measurement (source: developed by the authors)

carried out in an active market (i.e. the initial data of the 1st level, which does not require the use of professional judgment). In the absence of observation of current market data on the price of a financial instrument (as an object of evaluation) of the 1st level for evaluation it is necessary to use other indicators, which may be:

- recent transactions with this object of valuation, including transactions carried out after the reporting date. It should be kept in mind that these transactions do not always reflect market conditions at the reporting date. That is when forming a professional judgment about the adjustments should take into account, for example, changes in market conditions between the date of assessment and the date of the transaction, as well as whether the transaction is a forced agreement (due to the need for urgent sale), etc;

- current or recent transactions with similar instruments ("analog price"). This price should be adjusted to take into account differences between the counterparty and the asset, such as the difference in liquidity or credit risk that exists between the two financial instruments as the use of $\$ 38$ of IFRS 13 Fair Value Measurement. At the same time, it is also necessary to apply professional judgment regarding the presence and magnitude of risks;

- indices relating to similar instruments. As in the case with similar instruments, to take into account differences between the object of evaluation and the instrument or instruments on which the index is based adjustments will be required.

In the absence of an active market, substitutes for fair value are subjective assessments that involve the professional judgment of the appraiser. "In practice", according to V. Kovalev and Vit. Kovalev (2012, p. 607), it is subjective assessments that dominate market prices. Imagine, the authors suggest to the reader, that you need to show in the balance sheet at a fair value a machine purchased three years ago. Obviously, there is no market for such old equipment, so there is no market value, and instead will be used and the valuation made by the appraiser. In this case, the logic of fair value formation is based on the appraiser's ability to calculate the value of the object from the standpoint of its participation in the generation of future income.

To illustrate, the European Securities and Markets Authority (ESMA) case study on the completeness of the disclosure of level 3 derivatives of the fair value hierarchy - the amount of net income of an investment fund that leases real estate. ESMA found erroneous the professional judgment of the accountant of this fund that the amount of net rental income is not significant in determining fair value, and that additional disclosure is not required (Belyaeva, 2017).

As the degree of estimation uncertainty increases, the requirements for the amount and level of detail of the information disclosed should increase. The more factors are taken into account (for example, possible factors influencing the profitability of financial instruments, information on which is obtained according to the level 3), the more comments for each of them should contain a formalized document, which provides professional judgment.

The risk of using professional judgment in accounting valuation is the probability of distortion of legally significant characteristics of the object of evaluation both in the 
process of interpretation of legislation and as a result of the formation of erroneous and/or incomplete idea of the value of the object.

The main risks, in our opinion, are related to subjectivity and uncertainty in the perception of the source data. Subjectivity is psychologically motivated and conditioned either by ethical aspects (potential interest in consciously distorting information obtained through professional judgment) or by the low competence of the evaluator.

Instead, the risks of uncertainty arise due to the lack of initial data on the components of the value of the financial instrument. The risk increases if such a cost consists of several elements for which, due to the lack of precedents for the evaluation of analogs, it is complicated to obtain the original data. In the author's opinion, the existence of such risks should be noted in the document on the expression of professional judgment.

Uncertainty means that financial instruments reflected in accounting and reporting may change significantly in the future due to uncertainties in the reporting period. Therefore, IAS 1 "Presentation of Financial Statements" requires disclosures about future assumptions and other significant sources of uncertainty at the end of the reporting period if they carry a significant risk of material adjustments to the carrying amount of assets and liabilities in the next reporting period. This standard also requires

Table 2. Application of professional judgment in determining the value of inventories under the legislation of Ukraine and IAS (source: developed by the authors based on the source:

$\mathrm{P}(\mathrm{S}) \mathrm{BO} 9$ Inventories and IAS 2 Inventories)

\begin{tabular}{|c|c|c|c|}
\hline $\begin{array}{l}\text { Subject of } \\
\text { application }\end{array}$ & $\begin{array}{l}\text { Provisions of normative acts of Ukraine, which } \\
\text { provide for the use of professional judgment in } \\
\text { the assessment of stocks }\end{array}$ & $\begin{array}{l}\text { The norm of the relevant IAS, } \\
\text { which provides for the use } \\
\text { of professional judgment in } \\
\text { inventory valuation }\end{array}$ & Comment \\
\hline $\begin{array}{l}\text { Determining } \\
\text { the method of } \\
\text { valuation of } \\
\text { goods upon } \\
\text { receipt (retail) }\end{array}$ & $\begin{array}{l}\text { Upon receipt of goods, the company reflects the } \\
\text { amount of trade margin. There are two options } \\
\text { for forming a trade margin: } \\
\text { 1) sets the size of the trade margin on goods (as a } \\
\text { percentage of the original cost of goods) by order } \\
\text { of the head; } \\
\text { 2) first set the selling price of the goods, and } \\
\text { then the reverse account determines the amount } \\
\text { of trade margin. When choosing the optimal } \\
\text { method, professional judgment is used. } \\
\text { In both cases, the cost of selling goods will } \\
\text { consist of the purchase price of goods and the } \\
\text { amount of trade margin }\end{array}$ & $\begin{array}{l}\text { The cost of inventories is } \\
\text { determined by reducing the } \\
\text { selling price of inventories by an } \\
\text { appropriate percentage of gross } \\
\text { profit. Hence - the gross profit } \\
\text { from the sale of goods at retail } \\
\text { is equal to the trade margin } \\
\text { from the sale of goods. } \\
\text { Trade discounts, other } \\
\text { discounts, discounts, and } \\
\text { similar items are deducted } \\
\text { when determining the cost of } \\
\text { purchasing goods }\end{array}$ & $\begin{array}{l}\text { When reflecting the } \\
\text { financial result from } \\
\text { the sale should write } \\
\text { off the accrued trade } \\
\text { margin on sold goods } \\
\text { using the method of "de- } \\
\text { recognition" }\end{array}$ \\
\hline $\begin{array}{l}\text { Estimation of } \\
\text { stocks received } \\
\text { free of charge }\end{array}$ & At fair value & At fair value & $\begin{array}{l}\text { Fair value is a result } \\
\text { of the professional } \\
\text { judgment }\end{array}$ \\
\hline $\begin{array}{l}\text { Valuation of } \\
\text { inventories at } \\
\text { the balance sheet } \\
\text { date }\end{array}$ & $\begin{array}{l}\text { At the lowest of the two estimates: the initial } \\
\text { cost or net realizable value. In this case, the net } \\
\text { realizable value of inventories as the expected } \\
\text { selling price of inventories in the ordinary course } \\
\text { of business less the expected costs of completion } \\
\text { and sale is determined by judgment }\end{array}$ & $\begin{array}{l}\text { At the lowest of the two } \\
\text { estimates: the initial cost or net } \\
\text { realizable value }\end{array}$ & \\
\hline \multirow{6}{*}{$\begin{array}{l}\text { The choice } \\
\text { of method of } \\
\text { estimating stocks } \\
\text { at their disposal }\end{array}$} & Specific identification of their individual costs & $\begin{array}{l}\text { Specific identification of their } \\
\text { individual costs }\end{array}$ & \multirow{6}{*}{$\begin{array}{l}\text { The subject of } \\
\text { professional judgment is } \\
\text { the choice of the optimal } \\
\text { method of assessing the } \\
\text { disposal of the proposed } \\
\text { alternative standards }\end{array}$} \\
\hline & Weighted average cost formula & Weighted average cost formula & \\
\hline & First-in, first-out (FIFO) & First-in, first-out (FIFO) & \\
\hline & Techniques for the Measurement of Cost & $\begin{array}{l}\text { Techniques for the } \\
\text { Measurement of Cost }\end{array}$ & \\
\hline & Standard cost & Standard cost & \\
\hline & Sales prices & Retail price method & \\
\hline $\begin{array}{l}\text { Estimation of } \\
\text { stocks owned } \\
\text { by commodity } \\
\text { brokers-traders }\end{array}$ & - & Valuation at fair value & - \\
\hline $\begin{array}{l}\text { Determining the } \\
\text { need to create } \\
\text { a reserve to } \\
\text { reduce the cost of } \\
\text { inventories }\end{array}$ & $\begin{array}{l}\text { Obsolete inventories have lost all or part of their } \\
\text { original quality or current market value, the sale } \\
\text { price of which has decreased, are reflected in the } \\
\text { balance sheet at the end of the reporting year less } \\
\text { the provision for impairment of property, plant, } \\
\text { and equipment }\end{array}$ & - & $\begin{array}{l}\text { The subject of } \\
\text { professional judgment is } \\
\text { to determine the fact and } \\
\text { value of the obsolescence } \\
\text { of stocks, the loss of their } \\
\text { original qualities }\end{array}$ \\
\hline
\end{tabular}


disclosure of the professional judgment that managers make in applying their organization's accounting policies and that have the most significant effect on the amounts recognized in the financial reports metrics.

Another important object of evaluation for the application of professional judgment is inventories. International and national financial accounting and reporting standards provide for the use of professional judgment in determining the value of inventories from their receipt to disposal in the event of an alternative. A summary of the possibilities of such an application of evaluative judgments is given in Table 2.

Practically the result of the expression of professional judgment should be a documentary medium of a certain form. Companies independently develop such a document under the needs of the business, the degree of risk, the object of evaluation, and other factors of professional judgment. This document, in the author's opinion, should be included in the Order on the accounting policy of the company (see Figure 3). Such a document will contribute to some regulation of such new (for countries with economies in transition) activities of accountants and be a tool to increase the responsibility of professional accountants.

Such a document will contribute to some regulation of such new (for countries with economies in transition) activities of accountants and will be a tool to increase the responsibility of professional accountants.

In addition to financial reporting, the need for professional judgment arises in the preparation of other reports. A study (Docekalova et al., 2015), which aimed to identify the most significant economic indicators that affect corporate sustainability, shows that modern evaluation of corporate performance requires a multidimensional concept that has replaced their traditional understanding. Although corporate economic performance will remain a major interest for owners and investors, key shareholders need information on corporate governance, environmental and social factors. The main set of key indicators is based on the synthesis of resources from a number of international organizations (Global Reporting Initiative, International Federation of Accountants).

One of the main forms of reporting economic, environmental, and social information is an integrated report. The IIRF, even more so than the IAS, which lacks specific indicators, does not provide specific assessment methods and directly requires the professional judgment of those responsible for the preparation and presentation of this report. Objects of professional judgment in the process of preparing an integrated report differ from the objects of financial statements. The IIRF only names the main elements of the report and general questions about their content. The principle of materiality must be followed in order to determine the information to be provided in the report.

Therefore, the assessment of the materiality of the facts of the economic life of the company performs taking into account its known or potential effect on value creation, in particular: the magnitude of the matter's effect and, if it is uncertain whether the matter will occur, its likelihood of occurrence. $\$ 3.24$ IIRF provides the possibility of applying both quantitative and qualitative assessment of the extent of the impact of a particular factor.

At the same time, even the availability of reliable source data by $\$ 3.26$ IIRF does not exclude the need for professional judgment, as the questions to be answered by the integrated report require:

a) a preliminary assessment of the expected (impact) results (impact) in the short, medium and long term;

b) detection of changes in value, in particular, those types of capital for which a qualitative characteristic

On the formation of professional judgment on evaluation Object

Responsible person

Date of formation of the conclusion

Position First and last name

\begin{tabular}{c|l}
$\begin{array}{c}\text { Reporting date on which the } \\
\text { professional judgment is } \\
\text { expressed }\end{array}$ & Stocks transferred free of charge (their characteristics) \\
\hline Object of the evaluation & $\begin{array}{l}\text { Determining the fair value of gratuitously transferred inventories to determine their carrying } \\
\text { amount to display in the balance sheet }\end{array}$ \\
\hline $\begin{array}{c}\text { Goal of professional judgment } \\
\text { which is the basis of professional } \\
\text { judgment }\end{array}$ & $\begin{array}{l}\text { Indicate the data based on which the judgment is made (contractual basis, analysis of the } \\
\text { market of analogs), provide the relevant standards and other standards of accounting and } \\
\text { reporting (for instance, IAS 2 Inventories, or the relevant national standard). }\end{array}$ \\
\hline $\begin{array}{c}\text { Risks of professional judgment } \\
\text { judgment on evaluation }\end{array}$ & $\begin{array}{l}\text { Uncertainties are characterized by a possible lack of information about the object of } \\
\text { evaluation, the level of competence of the evaluator may be indicated }\end{array}$ \\
\hline $\begin{array}{l}\text { The factors based on which the judgment is made (contractual basis, analysis of the market of } \\
\text { analogs), and the judgment on the monetary expression of fair value (confirmation or } \\
\text { refutation) are made. }\end{array}$ \\
\hline
\end{tabular}

Responsible person signature date

Figure 3. Example of the accountant's report on the application of professional judgment on the object of evaluation (source: developed by the authors) 
is applied, namely intellectual, human, socio-reputational;

c) determining the nature of the change in the value of capital (increase, decrease or maintenance of value) depends on the chosen perspective;

d) accounting for capital (for example, productive) that is created by other organizations, but includes assets manufactured by the reporting organization for sale or when they are retained for its use;

e) taking into account external consequences that may increase or decrease the value created for the company (on increase or decrease value created for the organization).

Assessment of "external consequences" also has its specifics. Thus, Giorgino et al. (2017) draw attention to the fact that "the issue of corporate disclosure requires a consideration of not only (or not so much) the amount of (mandatory and voluntary) data disclosed, but also the materiality of the corporate communication, which is to be assessed while checking if the information provided is useful for the different stakeholders and their behaviors toward the organization". In this regard, it should be noted that this task requires a preliminary prioritization of stakeholders for a particular organization, etc.

In the conclusion, when evaluating objects in financial accounting, when determining the materiality of individual facts for their reflection in the integrated reporting, there may be contradictions. The solution of a particular contradiction is associated with the definition of alternatives, their analysis, and selection based on the application of professional judgment, taking into account the consequences of particular facts of life of the company. At the same time, increasing attention to the social responsibility of business requires taking into account not only the economic but also environmental and social external consequences of the company.

In this regard, professional judgment plays a crucial role in the preparation of reports that reflect corporate social responsibility. In particular, this applies to the disclosure of sustainability reporting under the GRI Standards. According to the GRI 101, these standards help each organization to determine what information on its economic, environmental, and/or social impacts, and hence its contributions - positive or negative - towards the goal of sustainable development should be reported. The performance of such a task directly depends on the ability of the compilers of the report to make a professional judgment about its significant impacts on the economy, the environment, and/or society. This gives grounds to argue about the increasing scope of the use of professional judgment of the accountant.

When compiling a system of reports (financial, integrated, and others), the initial data on the company's activities are subject to various analyzes according to different principles, which are defined by different regulations IFRS, Guidelines for the preparation of integrated reporting, GRI standards, etc. At the same time, the reporting should reflect not only past events and their consequences, but also anticipated events, future activities, and their expected results, probable risks and opportunities, factors that affect the value of the business in the short, medium, and long term. According to studies of best practices in integrated reporting (International Integrated Reporting Council, Summary of Significant Issues, 2013), 90\% of respondents point to the need to determine the base of indicators and measurement methods for integrated reporting. The problem is choosing the best basis among 118 different bases and methods. For each company, the choice of the best database of indicators and measurement methods depends on the professional judgment of its compilers.

Professional judgment about a particular object of accounting is inextricably linked to its recognition. This connection has a dual purpose. First, it is due to the need to identify and determine the appropriateness of the reflection of a particular fact in the system of accounting and reporting, and secondly - to ensure the necessary or sufficient level of reliability of the assessment of the object.

Professional judgment about a particular object of accounting and reporting is inextricably linked to its recognition. This connection has a dual purpose. First, it is due to the need to identify and determine the appropriateness of the reflection of a particular fact in the system of accounting and reporting, and secondly - to ensure the necessary or sufficient level of reliability of the assessment of the object.

Thus, the main factors that determine the need for professional judgment in accounting practice is the approach to the preparation of reports, which is based on the principles; variability of approaches to the recognition and measurement of reporting items; a reflection of social responsibility of business and introduction in the reporting of the enterprise of qualitative characteristics of its activity.

As a result, the requirements for the professional competence of the accountant (level of professional knowledge, practical experience, and personal qualities) increase. The transformation of the accounting profession, which occurs through the development of information technology, creates conditions for the application of analytical qualities of the accountant and the formation of professional judgment.

\section{Conclusions}

The use of professional judgment in the preparation of financial, integrated, and other forms of reporting of companies is an objective necessity. In this case, the objects of professional judgment of the accountant are the facts of economic activity in order to identify, evaluate, recognize and reflect in the accounting and reporting of the company objects of accounting that are significant and of interest to internal and external users.

The statistical analysis of scientific research on professional judgment in accounting and evaluation, suggests that this topic will remain relevant in the near future due 
to the need to study and provide recommendations for the use of professional judgment in the preparation of both traditional financial and new forms of reporting.

The article focuses on the factors that determine the qualitative characteristics of judgments and, above all, the "means of solving problems" and "process factors" of professional judgment as a basis for decision-making. The starting point of the article was to determine the purpose of the professional judgment of the accountant as a search for the best way to present reporting information, taking into account existing regulations.

The study of the essence and principles of professional judgment by an accountant as a starting point for evaluating and recognizing objects allowed us to formulate conclusions that can be grouped into clusters that have theoretical, methodological and practical nature and meet the purpose and objectives of the research.

As a conclusion on the theoretical task of the work determining the essence of the object of our study, we note that the professional judgment of the accountant can be described/characterized as a process of forming formalized conclusions on the recognition, condition, valuation, or other accounting characteristics (parameter, criterion) subject of accounting in conditions of uncertainty and lack of unambiguous regulation of requirements for such characteristics. In our opinion, the most reliable formation of professional judgment, which will take into account the full range of its various properties, will be complete provided that the postulate of additionality. The accountant's mission is to search for alternatives to evaluate a particular item, analyze the risks of using mutually exclusive options, choose between minimizing risk and maximizing revenue as a result of a management decision made on the basis of a judgment.

The application of professional judgment is complex and has a legal aspect - regulation (i.e. sanction for use in the legal environment range) and social aspect, as its use will increase the objectivity of accounting and reporting information, which will increase the informativeness, relevance, and transparency of data for all interested users. Also important is the ethical aspect of the application of judgments that directly depend on the professional integrity of the evaluator for sound and fair coverage of data, provided that their qualitative characteristics are ambiguous or contradictory.

The methodological aspect of the work is related to the study of the normative framework for the application of judgment and modeling of the processes of forming conclusions based on judgment. Modern normative documents - IFRS and national accounting standards (studied on the example of Ukrainian accounting standards) pay sufficient attention to the practice of professional judgment. First, there are regulations concerning evaluation and evaluation. The main deterrent to the widespread use of professional judgment by accountants in countries with economies in transition, such as Ukraine, is the conservatism of accountants and the reluctance to go beyond what is interpreted by the regulations.
Features of the application of professional judgment were considered in the example of accounting valuation of financial instruments and inventories. As a result of the research, a matrix model of application of professional judgment in accounting valuation was proposed, which was built taking into account zero, medium, and high levels of risk. The general principles of application of professional judgment in accounting valuation are visualized.

The example of financial instruments and inventories illustrates the exclusive role of professional judgment in determining the fair value of objects, taking into account current regulations and levels of risk of misrepresentation. The considered example of application of professional judgment in inventory valuation shows quite similar, but still not identical approaches to inventory valuation according to IAS 2 and national accounting standards.

An analysis of the logic of using professional judgment in determining the fair value on the example of valuation of financial instruments under IFRS 13 Fair Value Measurement allowed us to build a hierarchical model of the data used for such an assessment. The model reflects the dependence of the range of uncertainty in the valuation of a financial asset from the regression of the reliability of the original data, which ultimately increases the value of the professional judgment of the accountant.

To solve the problem of formalizing the accountant's judgment, a standard form of a document "On the formation of professional judgment on evaluation" was developed. The proposed document reflects the conditions (purpose, initial data, regulatory framework for making a judgment, the main risks) and the result of such a judgment on the example of inventory valuation.

Finally, the critical role of professional judgment in integrated reporting has become clear. It was found that the main factors that determine the need for professional judgment in accounting practice is the approach to reporting, which is based on the principles; variability of approaches to the recognition and measurement of reporting items; a reflection of social responsibility of business and introduction in the reporting of the enterprise of qualitative characteristics of its activity. The task of expressing professional judgment acquires a new meaning due to the need to express an opinion on the value of a business in the short, medium, and long term, on existing and potential risks and opportunities.

The total number of publications aimed at the use of professional judgment as a tool of accounting is estimated at thousands, and therefore, detailed analysis and systematization of the key provisions of these works should be the task of a separate and very large-scale study. However, we consider it necessary to emphasize the difference between our results and the work of some modern researchers.

Faced with the actual dichotomy in terms of harmonization of professional judgment with the requirements of regulations in the field of accounting and reporting, we consider it appropriate for accountants to take an initiative approach. Practitioners in countries with economies in transition, which are characterized by strict accounting 
regulations, should not be afraid to formulate their professional vision within the acquired competencies and flexible regulations.

In our opinion, the profile of further research in the field of application of professional judgment for accounting can include both theoretical developments on the limits of application and practical recommendations based on precedents for the formation of judgments - on individual objects of accounting, on the processes to be covered and on cases disclosure of information at the level of financial, non-financial, or integrated reporting. Further research, in addition to empirical methods to improve the quality of their results may conduct a survey among accountants practitioners. It can cover a wide range of issues related to the application of judgments: relative frequency of implementation, targeting of targets, methods of fixation, identification and assessment of risks, etc.

With the expansion of the scope of professional judgment of the accountant, additional requirements are established on his professional competencies and moral and ethical qualities. Minimization of the risks of professional judgment of an accountant under various conditions and the level of reliability of the original data causes necessity of the further scientific researches for the concretization of procedures of formation of professional judgment concerning accounting estimation of various objects of accounting and reporting, reflecting the quality characteristics of the enterprise and, consequently, the impact of professional judgment on efficiency business management. The spread of the practice of compiling integrated reports also encourages scientific research and formalization of approaches to choosing the best basis for determining the system of indicators and the choice of measurement methods when compiling integrated reports by companies.

\section{References}

Baker, C. R. (2017). The influence of accounting theory on the FASB conceptual framework. Accounting Historians Journal, 44(2), 109-124. https://doi.org/10.2308/aahj-10555

Baxter, S. (2016). Can you measure the unmeasurable? https:// integratedreporting.org/wp-content/uploads/2016/04/SalterBaxterMeasuringtheUnmeasurable.pdf

Belyaeva, N. (2017). Ozenka po spravedlivoy stoimosti: kogda eto vygodno. In MSFO na praktike, 1 . https://msfo-practice. ru/524064 (in Russian).

Bikiené, J. (2011). Problems of public sector accounting and financial reporting standards implementation into practice. Business: Theory and Practice, 12(2), 131-140.

https://doi.org/10.3846/btp.2011.14

Bonner, S. E. (1999). Judgment and decision-making research. Accounting Horizons, 13(4), 385-398. https://doi.org/10.2308/acch.1999.13.4.385

Born, M. (1963). Physica v zhizni moyego pokolenia. Izdatelstvo Inostrannoy literature (in Russian).

Brown-Liburd, H., Issa, H., \& Lombardi, D. (2015). Behavioral implications of big data's impact on audit judgment and decision making and future research directions. Accounting Horizons, 29(2), 451-468. https://doi.org/10.2308/acch-51023
Derun, I. (2017). Improvement of the essence of professional judgment in accounting of Ukraine. Technology Audit and Production Reserves, 2(4(34), 25-29.

https://doi.org/10.15587/2312-8372.2017.98277

Docekalova, M., Kocmanová, A., \& Koleňák, J. (2015). Determination of economic indicators in the context of corporate sustainability performance. Business: Theory and Practice, 16(1), 15-24. https://doi.org/10.3846/btp.2015.450

Durkin, M., Rose, J., \& Thibodeau, J. (2020) Can simple metaphors be used as decision aids to promote professional skepticism? Journal of Information Systems, 34(1), 47-60.

https://doi.org/10.2308/isys-52380

European Parliament \& Council of the European Union. (2013). Directive 2013/34/EU of The European Parliament and of The Council on the annual financial statements, consolidated financial statements and related reports of certain types of undertakings. https://eur-lex.europa.eu/legal-content/EN/ $\mathrm{TXT} /$ ?uri=CELEX\%3A32013L0034

Gao, P., \& Zhang, G. (2019). Auditing standards, professional judgment, and audit quality. The Accounting Review, 94(6), 201-225. https://doi.org/10.2308/accr-52389

Giorgino, M. C., Supino, E., \& Barnabe, F. (2017). Corporate disclosure, materiality, and integrated report: An event study analysis. Sustainability, 9(12), 2182.

https://doi.org/10.3390/su9122182

Golov, S. (2011). Kreatyvnyi oblik: zagroza profesii ta suspilstvu. Accounting and Auditing, 1, 31-42. (in Ukrainian).

Goroshko, A., Narchynska, T., Ozymok, I., \& Tarnay, V. (2016). Glossariy terminiv $z$ monitoring ta ozinyuvannya (2nd ed.). Kyiv (in Ukrainian). http://www.ukreval.org/images/publikacii/glossary.pdf

Gurina, N., \& Doyonko, A. (2019). Zastosuvannya profesiynogo sudzhennya bukhaltera $\mathrm{v}$ umovah rynkovoi ekonomiku: vitchiznyanuy ta mizhnarodniy dosvid. Economic Herald. Series: Finance, Accounting, Taxation, 3, 40-47 (in Ukrainian). https://doi.org/10.33244/2617-5932.3.2019.40-47

Heidhues, E., \& Patel, C. (2009). IFRS and exercise of accountants' professional judgments. In A. Cheng (Eds.), Insights and concerns from a German perspective (pp. 1-47). Macquarie University, NSW. http://hdl.handle.net/1959.14/1145862

Institute of Chartered Accountants of Scotland. (2012). Professional judgement framework for financial reporting. An international guide for preparers, auditors, regulators and standard setters. https://www.ifac.org/system/files/ uploads/PAODC/A-Professional-Judgement-Framework-forFinancial-Reporting.pdf

Knight, F. H. (1921). Risk, uncertainty, and profit. https://oll.libertyfund.org/titles/knight-risk-uncertainty-and-profit

Kovalev, V. V., \& Kovalev, Vit. V. (2012). Korporativniye finansi i uchet. Prospekt (in Russian).

Kulikova, L. I., \& Gubaidulina, A. R. (2017). Professionalnoye suzhdeniye bukhgaltera kak instrument formirovaniya finansovoi otchetnosti. Prospect (in Russian).

Kelly, K., Dinovitzer, R., Gunz, H., \& Gunz, S. (2019). The interaction of perceived subjectivity and pay transparency on professional judgment in a profit pool setting: The case of large law firms. The Accounting Review, 95(5), 227-246. https://doi.org/10.2308/accr-52612

Len, V., \& Nekhai, V. (2016). Profesiyne sudzhennya bukhgaltera: vyznachennya ponyattya ta zmisty. Accounting and Finance, 3, 21-30 (in Ukrainian).

Madsen, P. (2011). How standardized is accounting? The Accounting Review, 86(5), 1679-1708.

https://doi.org/10.2308/accr-10102 
Mathews, M. R., \& Perera, M. H. B. (1996). Accounting theory \& development (3th ed.). Nelson.

Pankova, S. V., \& Satalkina, Y. V. (2011). Professionalnoye suzhdeniye bukhgaltera i auditora: shodstva i razlichiya. Mezhdunarodniy bukhgalterskiy uchet, 21(171) (in Ukrainian).

Simon, H. (1955). A behavioral model of rational choice. The Quarterly Journal of Economics, 69(1), 99-118. https://doi.org/10.2307/1884852

Sokolov, Y. V., \& Terentyeva, T. O. (2001). Professionalnoye suzhdeniye bukhgaltera: itogi minuvshego veka. Bukhgalterskiy uchet, 12 (in Russian).

Tarasova, T. O. (2017). Accounting judgement as basis of innovative development of accounting and analytical management [Profesiyne sudzhennya bukhgaltera yak osnova innovatsiynogo rozvitku systemy oblikovo-analitichnogo zabezpechennya upravlinnya]. Problems of Theory and Methodology of Accounting, Control and Analysis, 1(36), 260280 (in Ukrainian).

https://doi.org/10.26642/pbo-2017-1(36)-260-280

The Chinese Institute of Certified Public Accountants. (2016, May 31). Guidance on Professional Judgment for CPAs in China. https://professionaljudgmentmatters.blogspot.com/2016/05/ guidance-on-professional-judgment-for.html
The Institute of Chartered Accountants of Scotland. (2016). Professional judgement framework for financial reporting. In An international guide for preparers, auditors, regulators and standard setters (2nd ed.). https://www.icas.com/_ data/assets/pdf_file/0018/256104/Professional-judgementframework.pdf

Tintner, G. (1941). The Theory of choice under subjunctive risk and uncertainty. Econometric, 9, 298-304. https://doi.org/10.2307/1907198

Vyzhletsov, G. P. (2005). Filosofiya ekonomicheskih tsennostey. Problema tsennosti v sovremennoi aksiologii i ekonomike. Problems of Modern Economics, 3/4(15/16). http://www.meconomy.ru/art.php?nArtId=780 (in Russian).

Yukhimenko-Nazaruk, I. A. (2016). Instituziyni zasady zduysnennya profesiynogo sudzhennya $\mathrm{v}$ bukhalterskomy obliku. Economic Sciences. Scientific Bulletin of Kherson State University. Series, 21(1), 185-188 (in Ukrainian).

Yildiz, T., \& Yercan, F. (2011). Environmental reporting of industrial and supply chain business processes within the context of sustainable development. Business: Theory and Practice, 12(1), 5-14. https://doi.org/10.3846/btp.2011.01 